\author{
RENATA KUSIAK-WINTER \\ ORCID: 0000-0002-8202-1360 \\ Uniwersytet Wrocławski \\ Instytut Nauk Administracyjnych \\ Zakład Ustroju Administracji Publicznej
}

\title{
SAMORZĄD TERYTORIALNY W PERSPEKTYWIE STEROWANIA PRZEZ RACJONALNEGO PRAWODAWCE,
}

\begin{abstract}
Abstrakt: Założenie racjonalnego prawodawcy to nieodłączny element argumentacyjny klasycznej dogmatyki prawniczej i prima facie nie przystaje do koncepcji sterowania, która została wypracowana na gruncie szeroko pojętych nauk administracyjnych i która zajmuje się celowym i zamierzonym kształtowaniem rzeczywistości społecznej. Jednak zwłaszcza w odniesieniu do samorządu terytorialnego, jako podmiotu samodzielnego, działającego w imieniu własnym i na własną odpowiedzialność, rozpatrywanie tej instytucji ze szczególnym uwzględnieniem ambiwalencji podmiotu sterowanego i jednocześnie sterującego otwiera interesującą perspektywę badawczą.
\end{abstract}

Słowa kluczowe: racjonalny prawodawca, sterowanie przez prawo, samorząd terytorialny

I. Rozpatrywanie zagadnienia samorządności w kontekście sterowania sugeruje, że mamy do czynienia z rodzajem oksymoronu. Samorządność jest bowiem określoną emanacją niezależności, samostanowienia o swoich sprawach czy swoistej autonomii, podczas gdy sterowanie zakłada istnienie podmiotu (lub przedmiotu) sterującego oraz podmiotu (lub przedmiotu) sterowania, co wyklucza samorządność tego drugiego. Jednak wydaje się, że przyjęcie optyki badawczej sterowania przez prawodawcę w odniesieniu do samorządu terytorialnego jest ze wszech miar uzasadnione. Przyjęty bowiem w Polsce konstytucyjnoprawny model decentralizacji władzy publicznej zakłada, że samorząd terytorialny wykonuje istotną część zadań publicznych w imieniu własnym i na własną odpowiedzialność (art. 16 ust. 2 Konstytucji Rzeczypospolitej Polskiej). Jednocześnie formuła samorządności doznaje ograniczenia z uwagi na obowiązek działania organów władz publicznych na podstawie i w granicach prawa (art. 7 Konstytucji RP). O ile zatem można powiedzieć, że art. 16 ust. 2 jest kwintesencją samorządności jednostek terytorialnych, o tyle zasada legalności, ujęta w art. 7 Konstytucji, stanowi podstawę sterowania samorządem poprzez prawo. 
Należy podkreślić, że rozpatrywanie samorządu terytorialnego w kontekście zasady legalności jest zagadnieniem często poruszanym we współczesnym orzecznictwie oraz w literaturze przedmiotu i zajmuje ważne — jeśli nie najważniejsze - miejsce w toczącym się dyskursie na temat dopuszczalnych granic samorządności. Przedmiotowe wyroki Trybunału Konstytucyjnego stanowią w tym zakresie ważny punkt odniesienia, by przypomnieć chociażby wielokrotnie cytowany wyrok z 1998 roku, w którym Trybunał podkreśla, że: „,samodzielność jest wartością chronioną, lecz nie absolutną. Ochrona tej wartości nie może wykluczać lub znosić całkowicie albo w istotnej części prawa ustawodawcy do kształtowania stosunków w państwie. Samodzielność ta polega między innymi na działaniu samorządu w ramach ustaw" 1 . Jednakowoż należy wskazać, że równie wiele cytowań posiada inny ważny wyrok, w którym Trybunał podnosi znaczenie zasady samodzielności, gdzie każda ingerencja w sferę samodzielności samorządu terytorialnego wymaga zachowania formy ustawowej oraz zupełności uregulowania, tak by nie mogło być interpretowane rozszerzająco, a ingerencja nie może być nadmierna² ${ }^{2}$

Odnosząc koncepcję sterowania przez prawo do zasady praworządności, należy stwierdzić, że są to dwie odmienne kategorie wypracowane na gruncie odmiennych nauk - odpowiednio: nauki prawa oraz szeroko pojętych nauk administracyjnych, zwłaszcza socjologii i politologii. O ile nauka prawa zajmuje się analizą tekstu prawnego głównie za pomocą metody formalno-dogmatycznej, o tyle koncepcja sterowania (governance) kieruje wzmożoną uwagę na aspekty środowiskowe, zajmując się celowym i zamierzonym kształtowaniem rzeczywistości społecznej ${ }^{3}$. Niezmiernie istotne jest przy tym, że koncepcja sterowania wyróżnia szeroką paletę mediów sterowania, by wspomnieć w tym miejscu medium rynku, organizacji, budżetu czy kadr ${ }^{4}$, nie dokonując przy tym ich gradacji czy wartościowania ${ }^{5}$. W związku z tym pojawia się pytanie o zasadność podejmowania tytułowego zagadnienia. Otóż wydaje się, że podstawowym argumentem jest notoryczna doniosłość i aktualność tematyki w warunkach demokratycznego sprawowania władzy w państwie oraz konieczność poszukiwania nowych instrumentów badawczych do lepszego zrozumienia regulacji prawnych oraz istoty samorządu terytorialnego jako konstrukcji normatywnej. Chodzi zatem już nie tylko o analizę tytułowego zjawiska jako konstrukcji zapisanej w prawie (rozumianej jako struktura myślowa), ale również jako mechanizmu społecznego, na co zwró-

1 Wyrok TK z dnia 4 maja 1998 roku, K 38/97, OTK ZU nr 3/98, poz. 31.

2 Wyrok TK z dnia 15 kwietnia 2002 roku, K 23/01, OTK ZU nr 2/A/2002, poz. 19.

3 R. Maynz, O wybiórczości teorii sterowania z wprowadzeniem Boba Jessopa, ,Zarządzanie Publiczne" 2008, nr 1 (3), s. 143 n.

${ }^{4}$ G.F. Schuppert, Verwaltungswissenschaft, Berlin 2000, s. 455.

5 Przykładowo w socjologii czy politologii wyrażany jest sceptycyzm co do sterowalności systemów, w tym wobec zdolności sterowania poprzez prawo - zob. N. Luhmann, Politische Steuerung, „Politische Vierteljahresschrift” 1989, s. 4 n; idem, Die Gesellschaft der Gesellschaft, wyd. 1, Frankfurt a. Main 1997. 
cił uwagę Franciszek Longchamps w swoim studium poświęconym problemom poznania prawa z 1968 roku, stanowiącym do dziś ważne źródło inspiracji przedstawicieli doktryny ${ }^{6}$. Przypomnijmy, że wedle tego autora prawo jako konstrukcja myślowa jest poznawane dzięki dogmatyce prawa, czyli poprzez wykładnię tekstów prawnych, ich konceptualizację, porządkowanie, usuwanie sprzeczności i zapełnianie tak zwanych luk w prawie ${ }^{7}$. Natomiast prawo jako mechanizm społeczny traktowane jako część rzeczywistości społecznej, daje się poznać za pomocą badań empirycznych, które pozwalają na ustalenie, czy i w jakim zakresie prawo jest stosowane i oddziałuje na rzeczywistość społeczną poprzez osiąganie zamierzonych celów ${ }^{8}$. Stosując współczesną terminologię nauk administracyjnych, możemy powiedzieć, że owo oddziaływanie to sterująca zdolność prawa ${ }^{9}$.

Odnosząc interesujące nas zagadnienie do istoty racjonalnego prawodawcy, należy podkreślić, że zostało ono wypracowane na gruncie dogmatyki prawa, kierującej podstawową uwagę na reguły poprawnej legislacji oraz znajomość całego systemu prawnego, dzięki czemu poszczególnym słowom i zwrotom w tekście prawnym jest nadawane zawsze to samo znaczenie, bez zamieszczania sformułowań zbędnych ${ }^{10}$. W związku z tym powstaje uzasadnione pytanie o rolę racjonalnego prawodawcy w koncepcji sterowania poprzez prawo, zwracającej uwagę na techniki oddziaływania na rzeczywistość społeczną i na osiąganie zamierzonych celów. Przyjęcie takiej optyki badawczej jest podyktowane dbałością racjonalnego prawodawcy o skuteczność prawa, czyli traktowanie norm prawnych jako narzędzia do osiągnięcia założonych celów ${ }^{11}$. Wyraża się to również w przekonaniu, że racjonalny prawodawca, szanując konstytucyjne zasady państwa prawnego ${ }^{12}$, tworzy przepisy nie tylko w sposób sensowny i racjonalny, ale i celowy ${ }^{13}$ oraz posiada jednocześnie szerokie spojrzenie, gdyż „kieruje się w specjalny sposób swą wiedzą i ocenami, które wyznaczają pewne wartości"14.

$\mathrm{W}$ odniesieniu do administracji rozpatrywanie prawa jako medium sterowania rzeczywistością społeczną jest przejawem traktowania nauki prawa administracyj-

${ }^{6}$ F. Longchamps, Z problemów poznania prawa, Wrocław 1968, s. 18.

7 Ibidem, s. 8.

8 Ibidem, s. 20.

9 E. Knosala, Wspótczesna nauka prawa administracyjnego. Cele i metody badawcze, [w:] Nowe problemy badawcze w teorii prawa administracyjnego, red. J. Boć, A. Chajbowicz, Wrocław 2009, s. 308.

10 Z. Ziembiński, Teoria prawa, Warszawa 1978, s. 106-123; uchwała SN z 16 marca 2000 roku, sygn. akt I KZP 53/99; uchwała TK z 14 czerwca 1995 roku, sygn. akt W 19/94, OTK 1995/1/23.

11 Wyrok WSA w Gorzowie Wielkopolskim z dnia 29 listopada 2017 roku, sygn. akt II SA/ Go 960/17.

12 Zob. wyrok NSA z dnia 12 grudnia 2019 roku, sygn. akt I OSK 1976/19.

13 Z. Ziembiński, op. cit., s. 122; Postanowienie Sądu Najwyższego z dnia 22 czerwca 1999 roku, sygn. akt I KZP 19/99, OSNKW 1999/7-8/42.

14 M. Zieliński, Wykładnia prawa. Zasady, reguły, wskazówki, Warszawa 2017, s. 259. 
nego jako nauki sterowania ${ }^{15}$. W takiej optyce głównym zadaniem przedstawicieli nauki nie jest wyłącznie odkrywanie i dogmatyczne kształtowanie określonych zasad i instytucji prawnych, lecz również badanie uwarunkowań skuteczności prawa. Wówczas działanie jednostek samorządu terytorialnego w granicach i na podstawie prawa oraz kwestia umocowania władzy samorządu jawią się nie jako procesy konsystentne i linearne, przebiegające od góry do dołu, lecz jako procesy o złożonym charakterze i o wielokierunkowych zakresach oddziaływania. W konsekwencji kwestia legalności działania administracji samorządowej to już nie tylko kwestia kontroli prawnej, ale również podejmowanych działań administracyjnych $^{16}$.

II. Odnosząc optykę sterowania przez racjonalnego prawodawcę do tematycznego zagadnienia, należy stwierdzić, że samorząd terytorialny to już nie tylko obiekt sterowania przez prawodawcę, ale również podmiot sterujący rzeczywistością społeczną. Na gruncie teorii prawa takie ujęcie możemy zobrazować zjawiskiem wewnętrznego zróżnicowania prawa, zwłaszcza zaś systematyką norm prawnych o rozmaitej strukturze, zależnej od celów i funkcji, których realizacji dana norma służyć powinna. Innymi słowy — „potencjał” sterowalności prawem można prześledzić, analizując konstrukcję normy prawnej ${ }^{17}$.

Punktem wyjścia do rozważań może być przyjęcie skrajnej sytuacji, gdy prawo stanowione w parlamencie określa w sposób wyczerpujący zarówno cel, jak i metody realizacji prawa przez organy samorządu terytorialnego. Warunkiem jest taka konstrukcja normy, która determinuje całościowo wszystkie elementy procesu stosowania prawa i wówczas organ administracyjny jest zobowiązany do zadośćuczynienia wymogom formalnym ${ }^{18}$. Taka sytuacja ma miejsce przykładowo, gdy starosta poweźmie informację od funkcjonariusza policji, że kierowca przekroczył prędkość o więcej niż $50 \mathrm{~km} / \mathrm{h}$ w terenie zabudowanym. Wówczas sam fakt uzyskania tej informacji zobowiązuje starostę do wydania decyzji o zatrzymaniu prawa jazdy ${ }^{19}$, gdyż przepisy nie pozwalają na odstąpienie od wydania decyzji o takiej treści ${ }^{20}$. Ten jeden przykład uświadamia, że racjonalny prawodawca

15 E. Schmidt-Aßmann, Ogólne prawo administracyjne jako idea porzadku. Założenia i zadania tworzenia systemu prawnoadministracyjnego, przeł. A. Wasilewski, Warszawa 2011, s. 23 n.

16 Ibidem, s. 24.

17 W sprawie klasyfikacji norm prawa administracyjnego zob. między innymi A. Chełmoński, Typy norm prawnych materialnego prawa administracyjnego $i$ ich rola $w$ ksztaltowaniu sytuacji prawnej jednostki, „Przegląd Prawa i Administracji” 2, 1972, s. 71 n.

$18 \mathrm{Na}$ temat stopnia szczegółowości związania administracji prawem zob. J. Wróblewski, Stosowanie prawa przez organy administracji, „Organizacja — Metody — Technika” 1972, nr 12, s. $16 \mathrm{n}$.

19 Zgodnie z art. 102 ust. 1 pkt 4 ustawy z dnia 5 stycznia 2011 roku o kierujących pojazdami (Dz.U. z 2019 r. poz. 341).

${ }^{20} \mathrm{~W}$ tej sprawie zob. w szczególności uchwałę NSA z 1 lipca 2019 roku w sprawie I OPS 3/18 (LEX nr 2688159), w której sąd podkreślił znaczenie zarówno literalnej, jak i celowościowej wykładni przepisu z art. 102 ust. 1 pkt 4 ustawy o kierujących pojazdami. 
konstruując typ norm kondycjonalnych, które w sposób zupełny i wyczerpujący narzucają określoną konkretyzację elementów procesu stosowania prawa, wybiera opcję sterowania redukującą samodzielność administracji samorządowej do minimum. Dzieje się tak w sytuacjach, gdy wydanie decyzji o jednej tylko możliwej treści jest podyktowane koniecznością ochrony życia i zdrowia oraz bezpieczeństwa ludzi. Mamy wówczas do czynienia z brakiem samodzielności czy samorządności samorządu terytorialnego. Pojawia się w związku z tym pytanie, czy takie skrajne sytuacje można jeszcze określić mianem sterowania przez prawo czy raczej mamy tu do czynienia z prostym nakazem realizacji woli prawodawcy. Wydaje się, że należy się opowiedzieć za drugą z wymienionych opcji — w związku z naturą „sterowania”, które wywodzi się z języka żeglarstwa czy astronautyki i zakłada kierowanie naznaczone wieloma współczynnikami niepewności.

Na przeciwległym biegunie występuje typ sterowania poprzez prawo, które przewiduje możliwie szeroki zakres swobody działania organu. Wydaje się, że największą sferę samorządności lokalnej czy regionalnej prawodawca kreuje wówczas, gdy stanowi normy zadaniowe (programowe), konstruujące cel do zrealizowania i pozbawione przy tym szczegółowej determinacji prawnej. Egzemplifikację takiej regulacji stanowi art. 18 ust. 2 pkt 13 ustawy o samorządzie gminnym ${ }^{21}$, wedle którego podejmowanie uchwał w sprawach nazw ulic lub placów będących drogami publicznymi lub nazw dróg wewnętrznych w rozumieniu ustawy z dnia 21 marca 1985 roku o drogach publicznych należy do wyłącznej właściwości rady gminy. Taki sposób skonstruowania normy prawnej jest bez wątpienia wyrazem zaufania racjonalnego prawodawcy do władz gmin, które przejawia się w przekazaniu na szczebel samorządowy kompetencji do samodzielnego kształtowania nazw funkcjonujących w publicznej przestrzeni lokalnej. Samodzielne nadawanie nazw stanowi bowiem wyraz oddziaływania na świadomość społeczną mieszkańców, istotną również dla autoidentyfikacji wspólnoty, będąc manifestacją postaw ludzi przebywających w danym miejscu ${ }^{22}$. Swoistym przejawem utraty zaufania i zmiany w dotychczasowym i długoletnim sposobie myślenia prawodawcy w tym zakresie jest przyjęcie ustawy przewidującej obowiązek zmiany nazw jednostek organizacyjnych, jednostek pomocniczych gminy, budowli, obiektów i urządzeń użyteczności publicznej, w tym dróg, ulic, mostów i placów oraz pomników, jeżeli prowadzą one do propagowania komunizmu lub innego ustroju totalitarnego ${ }^{23}$. Z punktu widzenia koncepcji sterowania na uwage

${ }^{21}$ Ustawa z dnia 8 marca 1990 roku o samorządzie gminnym (tekst jedn. Dz.U. z 2019 r. poz. 506 ze zm.).

${ }^{22}$ M. Tabernacka, Kwestia (nie)pomijalności organów samorzadu terytorialnego w kontekście decydowania o nazwach ulic, maszynopis powielony.

23 Ustawa z dnia 1 kwietnia 2016 roku o zakazie propagowania komunizmu lub innego ustroju totalitarnego przez nazwy jednostek organizacyjnych, jednostek pomocniczych gminy, budowli, obiektów i urządzeń użyteczności publicznej oraz pomniki, Dz.U. z 2016 r. poz. 744 ze zm. (dalej: ustawa o zakazie propagowania komunizmu). 
zasługuje a fakt, że oto omawiana ustawa, stanowiąc lex specialis do norm o charakterze zadaniowym, zawiera narzędzie do przeobrażenia roli i funkcji organów jednostek samorządu gminnego z podmiotu sterującego w podmiot sterowany ${ }^{24}$. Ustawa o zakazie propagowania komunizmu przewiduje bowiem, że w przypadku niedopełnienia przez gminy obowiązku określonego w art. 6 ust. 1 wojewoda wydaje zarządzenie zastępcze w przedmiocie „,dostosowania” nazwy do dyspozycji wynikających z art. 1 wyżej wymienionej ustawy. W związku z powyższym, w procesie stosowania przepisów ustawy o zakazie propagowania komunizmu, podstawowe znaczenie przypisano zasadzie racjonalnego prawodawcy, nakierowanej na dokonanie systemowej i celowościowej interpretacji przepisów ustawy, która najlepiej sprosta wymogom tejże zasady i pozwoli wyważyć konstytucyjnoprawną wartość samorządności jednostek terytorialnych oraz działania na podstawie i w granicach prawa, przez co pozwoli zapobiec instrumentalizacji prawa do realizacji partykularnych interesów ${ }^{25}$.

III. Powyżej wskazano na dwa skrajne przypadki sterowania wyłącznie przez prawo. Wydaje się jednak, że atrakcyjność sterowania jako koncepcji analitycznej niebywale wzrasta w przypadkach badania wpływu prawa na kształt samorządności terytorialnej w połączeniu $\mathrm{z}$ innymi mediami sterowania. $\mathrm{W}$ tym celu należy uwzględnić szeroki wachlarz innych mediów i instrumentów sterowania wyróżnionych w takich naukach, jak politologia czy socjologia. Jak już wyżej wspomniano, obok powszechnie obowiązującego prawa potencjału sterowania upatruje się między innymi w medium rynkowym, organizacyjnym, instytucjonalnym, budżetowym czy kadrowym. I chociaż nie obowiązuje gradacja wspomnianych mediów czy różnicowanie między nimi, nie ulega wątpliwości, że w ujęciu nauk

${ }^{24}$ Art. 6a ust. 1 ustawy o zakazie propagowania komunizmu stanowi, że w przypadku niewykonania przez gminę zarządzenia zastępczego w terminie 30 dni od dnia jego wejścia w życie wojewoda zapewnia jego wykonanie na koszt gminy.

25 Analiza bogatego orzecznictwa sądów administracyjnych powstałego w związku ze stosowaniem ustawy o zakazie propagowania komunizmu wskazuje na eksponowanie zasady samodzielności jednostek samorządu terytorialnego, o której mowa w art. 165 Konstytucji RP. Przykładowo wyrokiem z dnia 14 lutego 2018 roku, II OSK 254/18, NSA oddalił skargę kasacyjną od wyroku dotyczącego rozstrzygnięcia nadzorczego wojewody w przedmiocie zmiany nazwy ulicy, wydanego na podstawie art. 2 ust. 1 ustawy o zakazie propagowania komunizmu. NSA podkreślił, że analizując legalność rozstrzygnięcia nadzorczego, należy brać pod uwagę konstytucyjny aspekt samodzielności samorządu terytorialnego (art. 165 ust. 2 Konstytucji). Konieczne jest uwzględnienie faktu, że na gruncie przepisów ustawowych sprawy ulic gminnych są sprawami własnymi gminy, a podejmowanie uchwał dotyczących nazw ulic należy do wyłącznej kompetencji gminy. Sąd przypomniał również, że zgodnie z art. 171 ust. 1 Konstytucji organami nadzorującymi działalność jednostek samorządu terytorialnego z punktu widzenia legalności są wyłącznie prezes Rady Ministrów, wojewodowie $\mathrm{i}$ - w zakresie spraw finansowych - regionalne izby obrachunkowe. Katalog ten jest zamknięty. Nie można zatem przyjąć, że opinia Instytutu Pamięci Narodowej powinna przesądzać o ocenie nazwy ulicy, to bowiem wojewoda powinien wyczerpująco i jednoznacznie wykazać sprzeczność uchwały rady gminy z prawem (za: Naczelny Sąd Administracyjny, Informacja o dziatalności sądów administracyjnych w 2018 roku, Warszawa, maj 2019, s. 329). 
prawnych sterowanie administracją publiczną powinno uwzględniać konstytutywną oraz prymarną rolę prawa. Specyfikę takiego podejścia oddaje jedna z najpopularniejszych definicji, wedle której administracja publiczna to „układ normatywny zanurzony w rzeczywistości" ${ }^{26}$. Definicja ta w pełni uwzględnia wymogi sprawowania władzy publicznej w demokratycznym państwie prawa, ale jednocześnie dostrzega wagę i aktualność uwarunkowań pozaprawnych. Stąd postulat podejścia holistycznego, w którym ocena sterujących właściwości prawa będzie uwzględniona $\mathrm{w}$ kontekście związku z innymi mediami sterowania, badanymi w odniesieniu do funkcjonalnych ekwiwalentów i odpowiednio ulepszanymi poprzez uzgadnianie $\mathrm{z} n \mathrm{nimi}^{27}$. Z uwagi na ograniczony zakres opracowania poniżej zostaną przedstawione wybrane rozwiązania normatywne, ilustrujące sterowanie przez medium prawa w połączeniu z medium rynku.

Należy podkreślić, że w sytuacjach, gdy medium sterowania poprzez prawo jest uzupełnione innym medium, dzieje się tak zawsze za zgodą racjonalnego prawodawcy, wyrażoną bezpośrednio lub w sposób dorozumiany. Dostrzeżenie możliwości jednoczesnego oddziaływania wielu mediów sterowania wpływa na sposób oceny skuteczności prawa, odzwierciedlając zasadę racjonalnego prawodawcy ${ }^{28}$.

Przykładem zaprojektowania w prawie ścisłej współzależności pomiędzy medium sterowania przez prawo oraz sterowania przez rynek jest konstrukcja reżimu zamówień publicznych, który obowiązuje w związku z realizacją zadań przez administrację publiczną ${ }^{29}$. Posługiwanie się rynkiem jako medium sterowania odzwierciedla oczekiwania racjonalnego prawodawcy wobec zachowania podmiotu sterowanego, które będą adekwatne do zachowań podmiotów z sektora biznesowego. Dosyć wymowna jest w tym zakresie praktyka organizowania przetargów dla dokonywania zakupów grupowych, przez co uczestniczące jednostki samorządu terytorialnego nie tylko wypełniają ustawowy obowiązek wyłonienia najkorzystniejszej (rynkowo) oferty, będąc podmiotem sterowanym, ale dodatkowo stają się podmiotem aktywnie sterującym rzeczywistością społeczną, gdyż w wyniku „współpracy zakupowej” wzmacniają swoją pozycję przetargową ${ }^{30}$.

${ }^{26}$ F. Longchamps, Założenia nauki administracji, Wrocław 1991 (reprint z 1949 roku), s. 5.

27 E. Schmidt-Aßmann, op. cit., s. 26.

28 W tym znaczeniu warto przytoczyć interpretację zasady racjonalnego prawodawcy w orzecznictwie sądów powszechnych, w którym wskazano: „Wszelkie zabiegi interpretacyjne powinny dążyć do odtworzenia w sposób jak najbardziej zbliżony intencji racjonalnego ustawodawcy. Stosowanie wyłącznie literalnej wykładni przepisów prawa, w sytuacji, gdy w sposób jednoznaczny nie rozstrzygają one wątpliwości interpretacyjnych powinno zostać uzupełnione wykładnią celowościową. Interpretowanym przepisom należy nadawać znaczenia, które uczynią je rozwiązaniami najtrafniejszymi prakseologicznie". Zob. wyrok Sądu Apelacyjnego we Wrocławiu, I Wydział Cywilny, z dnia 26 lutego 2015 roku, sygn. akt I ACa 1705/14.

29 Zob. ustawa z dnia 29 stycznia 2004 roku Prawo zamówień publicznych (Dz.U. z 2018 r. poz. 1986 ze zm.).

30 Jako przykład można tu powołać działania największej w Polsce grupy zakupowej wspólnego zakupu prądu na lata 2020-2021 w ramach Górnośląsko-Zagłębiowskiej Metropolii, w której 
Należy dodać, że jakkolwiek cena rynkowa stanowi w praktyce podstawowe kryterium wyboru oferenta ${ }^{31}$, to racjonalny prawodawca kreuje obowiązek uwzględnienia innych czynników, na przykład tych o charakterze środowiskowym $^{32}$, osłabiając tym samym znaczenie medium rynkowego. Przykładu swoistej symbiozy medium sterowania przez rynek z celami pozabiznesowymi dostarcza analiza unijnych regulacji prawnych, z których wynika, że medium rynku odgrywa aktualnie kluczową rolę dla realizacji celów Europejskiego Zielonego Ładu $^{33}$. Celom tym służą instrumenty obowiązujące już od dłuższego czasu, jak na przykład Europejski System Handlu Emisjami (UE ETS) ${ }^{34}$, który regulując koszty uprawnień do emisji $\mathrm{CO}_{2}$, kształtuje jednocześnie koszty produkcji i tym samym preferowane źródła energii w danym kraju członkowskim. Bardziej aktualny przykład to obowiązywanie systemu aukcji energii z odnawialnych źródeł energii $^{35}$, w którym jako podmioty sterujące mogą uczestniczyć operatorzy sieci dystrybucyjnej działający w ramach klastrów energii z udziałem jednostek samorządu terytorialnego ${ }^{36}$. Nie bez znaczenia dla realizacji celów Europejskiego Zielonego Ładu jest spoczywający na jednostkach komunalnych, zarządzających miejską (lokalną) infrastrukturą ciepłowniczą, prawny obowiązek budowania tak zwanego efektywnego systemu ciepłowniczego, w którym do produkcji ciepła

skład weszło 113 zamawiających (nie tylko podmioty wchodzące w skład GZM), zwiększając siłę negocjacyjną i uzyskując korzystniejsze stawki u sprzedawców.

31 W sprawozdaniu Prezesa Urzędu Zamówień Publicznych za rok 2018 czytamy, że „W 85,32\% udzielonych zamówień o wartościach poniżej progów unijnych zamawiający dokonywali wyboru oferty najtańszej spośród wszystkich złożonych ofert" — zob. https://www.portalpzp. pl/sprawozdanie-prezesa-urzedu-zamowien-publicznych-o-funkcjonowaniu-systemu-zamowien-publicznych-w-2018-r (dostęp: 28.03.2020).

32 Mowa tu przykładowo o środowiskowych kryteriach oceny ofert, w tym odwołaniu do efektywności energetycznej przedmiotu zamówienia, o czym stanowi art. 91 ust. 2 ustawy Prawo zamówień publicznych.

${ }^{33}$ Komunikat Komisji do Parlamentu Europejskiego, Rady Europejskiej, Rady, Komitetu Ekonomiczno-Społecznego i Komitetu Regionów Europejski Zielony Ład, COM/2019/640 final.

34 Zob. Rozporządzenie Komisji (UE) nr 1031/2010 z dnia 12 listopada 2010 roku w sprawie harmonogramu, kwestii administracyjnych oraz pozostałych aspektów sprzedaży na aukcji uprawnień do emisji gazów cieplarnianych na mocy dyrektywy 2003/87/WE Parlamentu Europejskiego i Rady ustanawiającej system handlu przydziałami emisji gazów cieplarnianych we Wspólnocie (Dz. Urz. UE L 302 z 18 listopada 2010, s. 1, z późn. zm.) oraz ustawa z dnia 12 czerwca 2015 roku o systemie handlu uprawnieniami do emisji gazów cieplarnianych, tekst jedn. Dz.U. z 2020 r. poz. 136.

35 Szerzej na ten temat zob. A. Pinkas, R. Nowakowski, Wyniki aukcji OZE w Polsce na tle European Green Deal - czyli co byto istotne dla energetyki w 2019 i co odegra kluczowa rolę w 2020, https://www.cire.pl/item,192856,13,0,0,0,0,0,wyniki-aukcji-oze-w-polsce-na-tle-european-green-deal----czyli-co-bylo-istotne-dla-energetyki-w-2019-i-co-odegra-kluczowa-role-w-2020.html (dostęp: 28.03.2020).

36 Zakładanie klastrów energii odbywa się na podstawie ustawy z dnia 20 lutego 2015 roku o odnawialnych źródłach energii, tekst jedn. Dz.U. z 2020 r. poz. 261. 
lub chłodu wykorzystuje się między innymi energię ze źródeł odnawialnych ${ }^{37}$. Natomiast milczenie prawodawcy w zakresie instrumentów i sposobów osiągania tejże efektywności oznacza otwarcie przestrzeni dla działań sterujących jednostek samorządu terytorialnego. Dodajmy, że niebagatelne znaczenie w wyborze kierunków działań sterujących ma system zachęt finansowych tworzonych w ramach programów rządowych czy unijnych, co nota bene stanowi przejaw sterowania przez medium budżetu.

Należy podkreślić, że sterowanie przez medium rynku nie zawsze podlega silnej determinacji prawnej. Mowa tu zwłaszcza o obowiązywaniu norm prawnych o charakterze programowym, które przewidują twórczą (sterującą) działalność jednostek samorządu terytorialnego. Jako przykład mogą tu posłużyć reformy nowego zarządzania publicznego przeprowadzane pod hasłem zarządzania urzędem (lub inną komunalną jednostką organizacyjną) jak organizacją biznesową w myśl prawideł performance management ${ }^{38}$. Jednym z takich przejawów jest wyróżnienie wśród zadań własnych ,promocji gminy”. Warto zauważyć, że norma zadaniowa sformułowana w art. 7 ust. 1 pkt 18 ustawy o samorządzie gminnym nie podlega szczegółowej determinacji prawnej, przyznając duży zakres samodzielności $\mathrm{w}$ działaniach promocyjnych gminy. W związku z powyższym powstaje uzasadnione pytanie o sposób oceny potencjału sterującego zawartego w tego typu normach zadaniowych, których realizacja odbywa się w oparciu o ogólne kryteria, obowiązujące w organizacjach biznesowych. Badania wykazują, że zdolność potencjału sterującego gminy będzie w tym zakresie uzależniona od prawidłowego planowania działań promocyjnych gminy na podstawie analizy potrzeb oraz określenia wskaźników osiągania celów i zadań promocyjnych, jak również monitorowania i dokonywania analizy osiągniętych efektów działań promocyjnych ${ }^{39}$.

IV. Założenie racjonalnego prawodawcy to nieodłączny element argumentacyjny klasycznej dogmatyki prawniczej i prima facie nie przystaje do koncepcji

37 Obowiązek osiągnięcia efektywnego systemu ciepłowniczego zawarty został w unijnej Dyrektywie o efektywności energetycznej z 25 października 2012 roku (2012/27/UE) oraz w ustawie o efektywności energetycznej z 20 maja 2016 roku (tekst jedn. Dz.U. z 2019 r. poz. 545 ze zm.). Dla uściślenia dodajmy, że mianem efektywnych są określane takie systemy ciepłownicze, w których do produkcji ciepła lub chłodu wykorzystuje się co najmniej w 50\% energię ze źródeł odnawialnych lub w 50\% ciepło odpadowe, lub w 75\% ciepło pochodzące z kogeneracji, lub w 50\% wykorzystuje się połączenie wyżej wymienionej energii i ciepła. Jak wskazują badania prowadzone w ramach rządowego programu Czyste powietrze, podłączenie do miejskiej sieci ciepłowniczej daje największy efekt w walce ze smogiem w mieście — zob. http://samorzad.pap.pl/depesze/wiadomosci_centralne/194576/Stop-kopciuchom--Sieci-cieplownicze-najbardziej-pomagaja-walczyc-zesmogiem-w-miastach (dostęp: 28.03.2020).

$38 \mathrm{Na}$ temat reform zrządzania publicznego zob. R. Kusiak-Winter, Performance Management w administracji publicznej - uwarunkowania, dylematy, wyzwania, „Samorząd Terytorialny” 2016, nr 11, s. $133 \mathrm{n}$.

$39 \mathrm{Na}$ ten temat zob. stosowne sprawozdanie Najwyższej Izby Kontroli, https://www.nik.gov. pl/aktualnosci/samorzady-w-rolach-glownych-czyli-o-promocji-gmin-wojewodztwa-swietokrzyskiego.html (dostęp: 28.03.2020). 
sterowania, która została wypracowana na gruncie szeroko pojętych nauk administracyjnych i która zajmuje się celowym i zamierzonym kształtowaniem rzeczywistości społecznej. Jednak zwłaszcza w odniesieniu do samorządu terytorialnego, jako podmiotu samodzielnego, działającego w imieniu własnym i na własną odpowiedzialność, rozpatrywanie tej instytucji ze szczególnym uwzględnieniem ambiwalencji podmiotu sterowanego i jednocześnie sterującego otwiera interesującą perspektywę badawczą. Podstawowa konkluzja niniejszych rozważań stanowi, że warunkiem adaptacji koncepcji sterowania na grunt nauk prawnych jest założenie racjonalnego prawodawcy, który szanując konstytucyjne zasady państwa prawnego, zakłada — inaczej niż w socjologii czy politologii — konstytutywny i wiodący charakter medium sterowania przez prawo, a jednocześnie przewiduje możliwość użycia innych mediów i instrumentów sterowania dla osiągnięcia celów i funkcji stawianych przepisom prawnym. Należy podkreślić, że propozycja wykorzystania koncepcji sterowania na gruncie nauk prawnych ma na celu nie tyle zastąpienie, ile uzupełnienie tradycyjnej metody formalno-dogmatycznej, kierując podstawową uwagę na aspekty skuteczności prawa.

\title{
TERRITORIAL SELF-GOVERNMENT FROM THE POINT OF VIEW OF GOVERNANCE BY A RATIONAL LAWMAKER
}

\author{
Summary
}

The concept of the rational lawmaker is an inherent part of classic legal dogmatics and, at first glance, does not suit the concept of governance that has been developed in the area of broadly-understood administrative studies and deals with the deliberate and intentional formation of social realities. However, viewing this institution as a controlled and simultaneously controlling entity opens up an interesting research perspective, especially with respect to territorial self-government, as an independent entity operating in its own name and at its own risk.

Keywords: rational lawmaker, governance by law, territorial self-government

\section{BIBLIOGRAFIA}

Chełmoński A., Typy norm prawnych materialnego prawa administracyjnego i ich rola w ksztaltowaniu sytuacji prawnej jednostki, „Przegląd Prawa i Administracji” 2, 1972.

Knosala E., Wspótczesna nauka prawa administracyjnego. Cele i metody badawcze, [w:] Nowe problemy badawcze $w$ teorii prawa administracyjnego, red. J. Boć, A. Chajbowicz, Wrocław 2009.

Korczak J., Konstytucyjne podstawy struktur i funkcji samorzadu terytorialnego, [w:] System prawa administracyjnego, t. 2. Konstytucyjne podstawy funkcjonowania administracji publicznej, red. R. Hauser, Z. Niewiadomski, A. Wróbel, Warszawa 2012.

Kusiak-Winter R., Performance Management w administracji publicznej-uwarunkowania, dylematy, wyzwania, „Samorząd Terytorialny” 2016, nr 11. 
Longchamps F., Z problemów poznania prawa, Wrocław 1968.

Longchamps F., Założenia nauki administracji, Wrocław 1991 (reprint z 1949 roku).

Luhmann N., Die Gesellschaft der Gesellschaft, wyd. 1, Frankfurt a. Main 1997.

Luhmann N., Politische Steuerung, „Politische Vierteljahresschrift” 1989.

Maynz R., O wybiórczości teorii sterowania z wprowadzeniem Boba Jessopa, „Zarządzanie Publiczne” 2008, nr 1 (3).

Naczelny Sąd Administracyjny, Informacja o działalności sądów administracyjnych w 2018 roku, Warszawa, maj 2019.

Pinkas A., Nowakowski R., Wyniki aukcji OZE w Polsce na tle European Green Deal - czyli co byto istotne dla energetyki w 2019 i co odegra kluczowa role w 2020, https://www.cire.pl/ item, 192856,13,0,0,0,0,0,wyniki-aukcji-oze-w-polsce-na-tle-european-green-deal----czyli-cobylo-istotne-dla-energetyki-w-2019-i-co-odegra-kluczowa-role-w-2020.html (dostęp: 28.03. 2020).

Schmidt-Aßmann E., Ogólne prawo administracyjne jako idea porządku. Założenia i zadania tworzenia systemu prawnoadministracyjnego, przeł. A. Wasilewski, Warszawa 2011.

Schuppert G.F., Verwaltungswissenschaft, Berlin 2000.

Tabernacka M., Kwestia (nie)pomijalności organów samorząu terytorialnego $w$ kontekście decydowania o nazwach ulic, maszynopis powielony.

Wróblewski J., Stosowanie prawa przez organy administracji, „Organizacja — Metody — Technika” 1972, nr 12.

Zieliński M., Wykładnia prawa. Zasady, reguły, wskazówki, Warszawa 2017, s. 259.

Ziembiński Z., Teoria prawa, Warszawa 1978. 